\title{
Formação continuada pós Pacto-BA e PNAIC: o ensino da leitura e da escrita no ERE à luz de fios discursivos freireanos
}

\author{
Continuing education after Pacto-BA and PNAIC: the teaching of reading and \\ writing in ERE in the light of freirian discursive threads
}

\author{
Márcia de Cássia Santos Mendes ${ }^{1}$ \\ Maria Aparecida Pacheco Gusmão²
}

\begin{abstract}
Resumo
Este artigo é um recorte de dissertação de mestrado com ênfase na formação continuada de três professoras que atuaram nos programas Pacto-BA e PNAIC considerando o ensino da leitura e da escrita no processo da alfabetização. O objetivo é apresentar aspectos dos postulados freireanos enfatizados e observados nas práticas das respectivas professoras, durante o Ensino Remoto Emergencial (ERE), 2020. Os instrumentos utilizados foram viabilizados por meio de aplicativos veiculados à cibercultura (SANTOS, 2019) com interfaces em Whatsapp, E-mail, Google Meet, canais de interlocução entre a pesquisadora e as professoras, para discussões sobre as cartas pedagógicas. Os diálogos propostos com as professoras contribuíram para e as ressignificações dos modos de ensinar e aprender. O resultado desta experiência, evidenciou que o movimento dialógico de formação continuada entre pesquisadora e professoras colaboradoras, ocorrida tanto presencialmente, quanto virtualmente, favoreceu o movimento reflexivo, a autoformação, a emancipação e o desenvolvimento profissional, possibilitando-lhes ressignificarem as ações didáticas em relação ao ensino da leitura e da escrita nos anos iniciais do Ensino Fundamental.
\end{abstract}

Palavras-chave: Formação continuada. PACTO/PNAIC. Leitura e escrita. Discursos freireanos.

\section{Abstract}

This article is an excerpt from a master's thesis with emphasis on the continuing education of three teachers who worked in the Pacto-BA and PNAIC programs, considering the teaching of reading and writing in the literacy process. The objective is to present aspects of Freire's postulates emphasized and observed in the practices of the respective teachers, during the Emergency Remote Teaching (ERE), 2020. The instruments used were made possible through applications conveyed to cyberculture (SANTOS, 2019) with interfaces in Whatsapp, E-mail, Google Meet, dialogue channels

\footnotetext{
1 Mestre em Ensino pela Universidade Estadual do Sudoeste da Bahia - UESB. Professora da Rede Estadual de Ensino do Estado da Bahia.E-mail: marcia.mendes@enova.educacao.ba.gov.br

2 Professora titular do Departamento de Estudos Linguísticos e Literários- DELL e do Programa de PósGraduação em Ensino, na Universidade Estadual do Sudoeste da Bahia - UESB. Email: aparecida.gusmao@uesb.edu.br
} 


\section{-Revista de Iniciação à Docência, v.6, n.2, 2021- \\ Publicação: dezembro, 2021 - ISSN 2525-4332}

between the researcher and the teachers, for discussions about the pedagogical letters. The dialogues proposed with the teachers contributed to and the resignifications of the ways of teaching and learning. The result of this experience showed that the dialogic movement of continuing education between researcher and collaborating teachers, which took place both in person and virtually, favored the reflective movement, selftraining, emancipation and professional development, enabling them to reframe the didactic actions in relation teaching reading and writing in the early years of elementary school.

Keywords: Continuing education. PACTO/PNAIC. Reading and writing. Freirian speeches.

\section{Introdução}

Este texto é um recorte da dissertação de Mestrado intitulada "Fios discursivos sobre o processo da leitura e da escrita: ressignificações da prática pedagógica pós Pacto/PNAIC no Ensino Remoto Emergencial" pelo Programa de Pós-graduação em Ensino (PPGEn), na Universidade Estadual do Sudoeste da Bahia (UESB), defendida em julho de 2021. As vertentes teóricas do estudo proposto abordaram as teorias enunciativo-discursivas de Bakhtin (2011), sociointeracionista de Vygotsky (1991; 2005) com ênfase na mediação e no arcabouço teórico freireano para quem a prática pedagógica é social, humana, humanizadora e transformadora (FREIRE, 2019), ponto que abordaremos neste artigo.

O contexto da pandemia da Covid-19 alterou todo o panorama mundial, em todos os aspectos e, consequentemente, também a educação foi afetada. Uma reorganização escolar, por meio do Ensino Remoto Emergencial (ERE) se impôs em todos os âmbitos do ensino, bem como em nossos estudos a nível de Pós-graduação.

Diante deste novo cenário, o objetivo do estudo é apresentar e discutir a prática pedagógica destas professoras pós-formação do Pacto-BA e PNAIC, considerando o contexto do Ensino Remoto Emergencial (ERE). Sendo assim, apoiamo-nos em alguns postulados teóricos freireanos para dialogar acerca da prática pedagógica, evidenciando os modos como as professoras ressignificaram em suas práticas o ensino.

O contato com as professoras colaboradoras ocorreu quando atuei como Formadora do Programa Pacto pela Educação, denominado como Pacto - BA e do Programa Nacional pela Alfabetização na Idade Certa - PNAIC com professores(as) do ciclo de alfabetização de 2013 a 2017 e, em alguns momentos, em 2018, nas salas de aula, observando o trabalho pedagógico. O ensino da leitura e da escrita nas salas de aula de muitos professores/as do ciclo de alfabetização $\left(1^{\circ}, 2^{\circ}\right.$ e $3^{\circ}$ anos), em muito se diferencia das experiências sociais do uso da linguagem efetiva pelas crianças, muitas vezes, o uso da linguagem emerge de modo artificial. 
O Programa Pacto- BA surgiu em 2011 em uma parceria entre o governo do Estado da Bahia e os respectivos municípios em regime de colaboração, tendo por objetivo assegurar a alfabetização das crianças começando com o $1^{\circ}$ ano para, em seguida, ir ampliando para o $2^{\circ}$ e para o $3^{\circ}$ ano do ensino fundamenta. Em 2014, uniu-se ao Programa Federal PNAIC, uma vez que ambos possuíam objetivos correlatos.

O lugar ocupado pela docência em nossos fazeres referente à prática pedagógica foi permeada por estudos freireanos, cuja base é o movimento, a busca, a reflexão acerca do fazer e sobre como fazer para assim, refazê-lo e, nesse encadeamento também refazer-se. Isto foi relevante para que não perdemos de vista "[...] a rebeldia que me confirma como gente e que jamais deixou de provar que o ser humano é maior do que os mecanicismos que o minimizam. " (FREIRE, 2019, p. 112-113). É com esta sabedoria que muitas professoras, contrariando a ideologia neoliberal resistem e tomam para a si a luta por uma educação viva que contribua com a melhoria de vida dos aprendizes.

Encontramos nos estudos de Freire (1986), a concepção de prática pedagógica que se constrói, na companhia dos sujeitos envolvidos, tendo em vista o conhecimento como processo em que ambos caminham em busca de práticas sociais que coadunam com a leitura crítica do mundo circundante

Há necessidade de formação continuada em que os postulados de Paulo Freire, referentes à prática pedagógica possam ser estudados e internalizados pelas professoras, firmados no diálogo, no respeito aos fazeres de quem ensina e de quem aprende, tendo em vista uma prática pedagógica em que transformar também ocasiona a transformação, emergindo nesse movimento amorosidade, ética, pesquisa e práxis, na acepção freiriana.

Concebemos o ensino da leitura e da escrita como processos que, embora com especificidades diferenciadas, não devem caminhar separados ou nas palavras freirianas implica engajamento crítico, emancipatório, amoroso porque está comprometido com uma práxis que emerge da necessidade de encaminhamento pedagógicos ancorados na humanização, em que todos e todas se percebam, na escola, como "colegas, amigos, irmãos."

Organizamos o texto em duas seções: na primeira explicitamos a metodologia e na segunda apresentamos e discutimos os resultados, guiando-nos por alguns fios discursivos freireanos. 


\section{Abordagem metodológica: a postura dialógica em busca do "pensar certo"}

“[...]ñão há ensino sem pesquisa e pesquisa sem ensino"

Os sujeitos que participaram do nosso estudo foram professoras que atuavam em paisagens diferentes dos Territórios de Identidades da Bahia3: Mucugê (na Chapada Diamantina), Quijingue (no Sisal) e Santa Inês (no Vale do Jequiriçá) com as respectivas crianças com as quais interagiam em sala de aula. Reiteramos que o diálogo promovido com as professoras levou em conta, desde o início, a experiência guardada do trabalho que elas desenvolviam na sala de aula, duas em turmas regulares e uma em turmas multisseriadas acerca da escrita de textos e da leitura.

Destacamos os desafios de ser observador participante em momento pandêmico tendo o ciberespaço como lócus, o que exigiu atenção, ainda mais cuidadosa do que o contexto presencial. Fizemos nossas as palavras de Martins (2020, p. 25) de que há necessidade de "[...] aceitação e confiança dos membros do grupo social no qual realiza o trabalho de campo. Para tanto, o êxito de uma pesquisa dessa natureza dependerá da capacidade do investigador de [...] integrar-se ao grupo".

A opção pela pesquisa-ação colaborativa e a observação participante ampliou as experiências discursivas gerando provocações mútuas, trazendo para as nossas reflexões, as interlocuções por meio dos três aplicativos alocados no ciberespaço, como também aquelas postuladas no Google Meet e nas trocas de mensagens via WhatsApp. $O$ ciberespaço é a internet habitada por seres humanos, que produzem, se autorizam e constituem comunidades e redes sociais por e com as mediações das tecnologias digitais em rede (SANTOS, 2019, p. 31).

O ciberespaço adentrou no estudo proposto porque estava em nossas ações (professoras e pesquisadora). Fomos "navegando" no intuito de conhecê-lo a partir de propósitos voltados para a aprendizagem. Dessa forma, passamos a nos conectar pelo Email, WhatsApp e Google Meet com vistas a mergulhar nas interações, ações, atitudes e, de igual modo, com o referencial teórico-metodológico.

A pesquisa colaborativa abriu portas para que estivéssemos atentas às motivações dos sujeitos envolvidos com a finalidade de que este "mergulho" pudesse gerar ações que contribuíssem para o estudo acerca do tema. Sendo assim, as reflexões sobre os modos de ensinar e aprender a escrever textos, com base nos saberes experienciais promovidos na e pela travessia, evidenciada por cada professora foram se sustentando no movimento prática-teoria e teoria-prática.

\footnotetext{
3 O Território de Identidade da Bahia é conceituado como um espaço físico, geograficamente definido, geralmente contínuo, caracterizado por critérios multidimensionais. Disponível em: http://www.seplan.ba.gov.br/modules/conteudo. Acesso em 22 out. 2019.
} 


\section{-Revista de Iniciação à Docência, v.6, n.2, 2021- \\ Publicação: dezembro, 2021 - ISSN 2525-4332}

Além disso, precisamos manter o convite todo tempo para que os sujeitos permanecessem motivados a participar de cada encontro. Nos eventos presenciais, 0 lócus que é a sala de aula está "pronta" com as professoras e as crianças dentro de um ambiente que já anuncia (com cartazes nas paredes, na disposição das carteiras e dos materiais didáticos) e com as enunciações tão características.

A atuação de cada uma era marcada pelo desejo e empenho para que as crianças lessem e escrevessem, por isso planejavam atentamente cada ação a realizar. Esse comprometimento evidenciava o senso de responsabilidade, amorosidade e ética para com a aprendizagem das crianças, mesmo faltando, às vezes, um conhecimento mais aprofundado sobre o trabalho referente à língua(gem).

Ibipiana (2016), anuncia que por meio do movimento reflexivo-colaborativo o trabalho de cada professora ou professor aflora contribuindo para a construção da identidade pessoal e profissional. O sentido atribuído à colaboração difere da cooperação porque o primeiro adota uma postura permanente de negociação e, não apenas, pela aceitação das ideias, por exemplo, da pesquisadora pelas professoras. A colaboração acolhe os saberes experienciais por intermédio da escuta sensível, em um processo enunciativo e dialógico em que todos e todas aprendem.

Assim, em consonância com Ibiapina (2008) é imprescindível que no âmbito da pesquisa colaborativa as negociações para tomadas de decisões coletivas transformam os colaboradores em "coparceiros, cousuários e coautores" dos processos construídos como investigativos. Afinal, Freire (2006, p. 100) sinaliza que "[...] não sou se você não é, não sou, sobretudo, se proíbo você de ser".

Estamos vivendo tempos mais duros, de desmandos, de fome, de opressão; tempo em que precisamos, nas palavras de Freire (2006) esperançar. Essa palavra infere que colhamos a herança crítica para desarmar as linhas de força e de poder. A educação, continua Freire (1997) é um exercício político, libertador, real, possível, mas necessariamente permanente.

$\mathrm{Na}$ esteira destas discussões, dividimos o trabalho em três etapas que se entrelaçam como propõe a figura abaixo: 
Figura 1: Etapas da pesquisa.

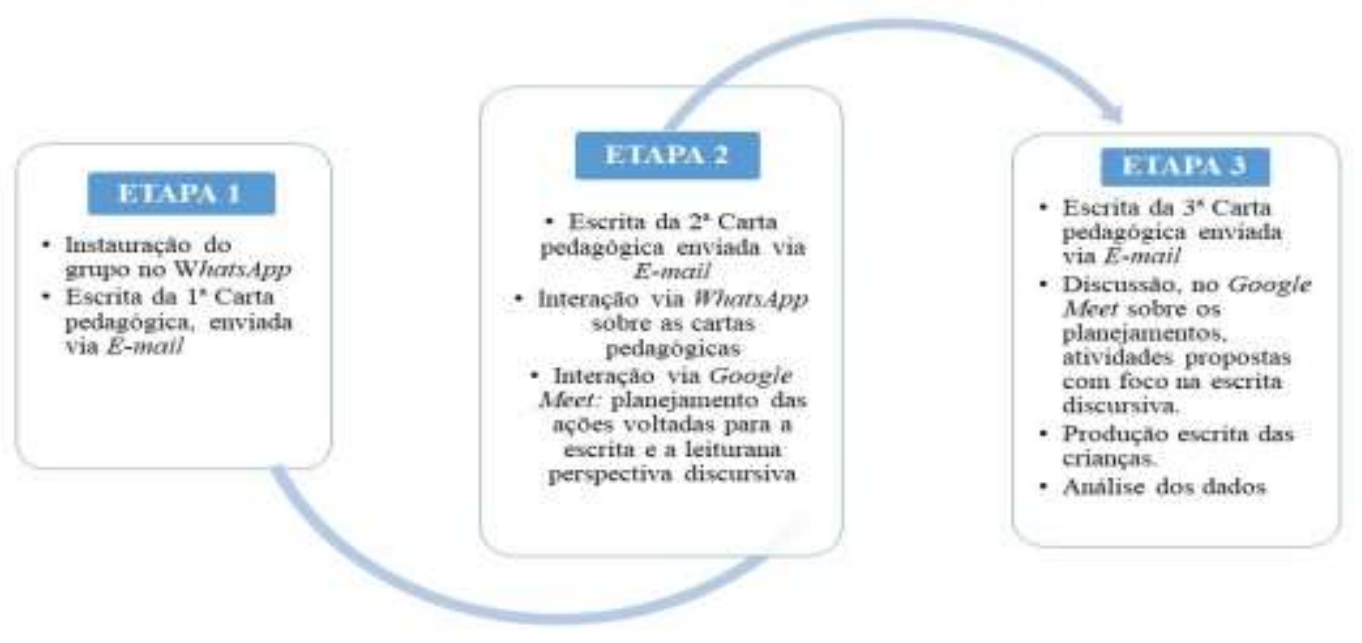

Fonte: Elaborada pelas pesquisadoras.

Com base nessas etapas, traçamos os instrumentos: cartas pedagógicas, planejamentos, produções escritas das crianças por E-mail, além dos prints das trocas de mensagens enviadas no WhatsApp. No mês de junho de 2020, sentimos necessidade de conversar, sendo assim fizemos a primeira chamada de vídeo pelo WhatsApp, mas a conexão não sustentou as quatro pessoas na tela. Em julho de 2020, incluímos as rodas de conversa, no Google Meet com a finalidade de analisar, a posteriori os dados com mais rigor teórico-metodológico. A partir da definição efetiva do ciberespaço elegemos como técnicas a observação participante e o diário de bordo, denominado "Caderno azul", assim consideramos as duas técnicas necessárias para compreensão do processo, não apenas para avaliar os resultados.

A Carta Pedagógica, enviada por E-mail possibilitou que as professoras colaboradoras, interlocutoras do discurso pudessem imprimir o estilo individual para dizer sobre a sua prática pedagógica no que se refere ao ensino da leitura e da escrita, sem perder o olhar para dentro, para as próprias experiências, visto o caráter subjetivo que permeia o gênero abordado.

Ao trazer aqui o gênero carta somos envolvidas pelas reminiscências da infância na aprendizagem da leitura e da escrita por meio das cartas. Mal sabíamos que estávamos fazendo uso da escrita como prática social. O gênero carta é aqui tomado como instrumento de pesquisa - Carta Pedagógica - inspirada na leitura de cartas freireanas. Trouxemos neste estudo a carta "velha" companheira para acolher o dizer de outrem para perto de nós. É neste sentido que as leituras das Cartas Pedagógicas postuladas por Freire (2000), trazem a escrita das vivências e também dizem sobre as concepções de cada uma e mais, registram como vão ressignificando os modos de ensinar e aprender ou aprender e ensinar a ler e a escrever. 


\section{A prática pedagógica: fios discursivos freireanos}

“[...] vamos nos fazendo aos poucos na prática social de que nos tornamos parte" Freire (2001, p. 80)

A leitura da Pedagogia do Oprimido (FREIRE, 2011) faz parte dos nossos estudos, desde 1984. Por meio dessa, a ressignificação dos saberes da experiência promovidos "no chão da escola" se impôs. Aos poucos, outras obras freireanas foram sendo acrescentadas em nossa vida cotidiana e pedagógica.

Aprendemos, como pontua Freire (2019), que o conhecimento não deve ser tomado por aquele ou aquela que ensina por replicar, transferir como se o sujeito aprendiz, ao chegar à escola não carregasse em sua bagagem as próprias experiências de vida, os seus desejos e, sobretudo, os seus direitos. Direito de usufruir de atividades que possam potencializar a apreensão do mundo social.

A compreensão de que a criança na escola não é mera receptora dos conhecimentos apresentados a ela no contexto em que está envolvida, e que a inserção dela no mundo é influenciada também pela história, pela cultura não assentada em uma "educação bancária (FREIRE, 2019). Aqui, reiteramos a escolha política pela palavra criança e, não estudante, aluno ou educando para não perder de vista que estamos diante de um sujeito de direitos, deveres e desejos e, não um "adulto em miniatura".

Um mundo real, vivo, cercado por múltiplas linguagens inclusas dialogicamente que estão à disposição da criança porque, ela é o sujeito que está no contexto social. Muitas vezes, a escola reduz o mundo em práticas pedagógicas que anulam a criatividade, a imaginação, a brincadeira, a escuta ativa sobre o que as crianças têm a dizer a respeito da história lida, do vídeo que assistiu, de uma brincadeira, entre outras.

Registramos o nosso modo de conceber a leitura a partir das palavras de Freire (1986, p. 15) “[...] ler não é só caminhar sobre as palavras, e também não é voar sobre as palavras. Ler é reescrever o que estamos lendo para descobrir a conexão entre o texto e o contexto do texto, e também como vincular o texto/contexto com o meu contexto, o contexto do leitor". Logo, a leitura é uma prática social, político necessária à vida humana. É uma prática que considera a formação à luz de um arcabouço teórico que promova a libertação dos sujeitos, não mais a opressão. Quanto mais a professora e o professor são leem criticamente mais chance terão de compreender a leitura como um ato libertador

Freire (1986), acrescenta que está a favor da seriedade intelectual, por isso é relevante conhecer o texto e o contexto, contudo devemos ser críticos todo tempo, porque a crítica cria a disciplina intelectual tão necessária para a ativar a compreensão frente ao lido, bem como ao que está sendo escrito porque não devemos ser submissos diante do texto. 


\section{-Revista de Iniciação à Docência, v.6, n.2, 2021- \\ Publicação: dezembro, 2021 - ISSN 2525-4332}

Nessa direção, o ensino e a aprendizagem devem se pautar nas experiências sociais que emergem da palavra viva de cada sujeito, da reflexão a respeito da palavra que escuta e diz com a finalidade de interação. Observamos que a colaboração entre os sujeitos além de fomentar a construção do objeto de conhecimento estudado, também contribui para desenvolvimento da formação humana, aproximando as crianças das relações sociais menos autoritárias que não estão centradas no apagamento da identidade do outro.

Compreendemos ainda mais, que a palavra é carregada por ideologia e no que diz sobre a aprendizagem leitora e escritora a quem interessa manter meninos e meninas pobres, negros e pardos, em sua maioria, amarrados a um ensino cujo foco do trabalho está ligado a uma concepção de linguagem que não incita o pensamento crítico, não autoriza o dizer com as próprias palavras, não escuta de modo sensível o dito do outro, que, por fim, tende a "encher" cada componente curricular de conteúdo não como um meio, mas um fim em si mesmo. Entregar apenas as atividades leitoras e escritoras para que professores e professoras do componente Língua Portuguesa assumam esse posto como únicos profissionais de leitura e escrita na escola é olhar para a língua(gem) de modo muito reducionista.

Em consonância com Freire (2011, p. 90-91), em Pedagogia do Oprimido:

A palavra verdadeira, que é trabalho, que é práxis, é transformar o mundo, dizer a palavra não é privilégio de alguns homens [e mulheres], mas direito de todos os homens [mulheres]. Precisamente por isto, ninguém pode dizer a palavra verdadeira sozinho, ou dizê-la para os outros, num ato de prescrição, com o qual rouba a palavra aos demais.

Neste ponto, pensamos ser relevante trazer os estudos freireanos sobre diálogo, tendo em vista aproximar da discussão apresentada, porque os sujeitos são dialógicos guardam a identidade, defendem o que são e, assim na troca de experiências aprendem um com o outro mediados pelo diálogo respeitoso (FREIRE, 2006).

Compreendemos nesse sentido que a aula é mediada pelo diálogo, por diferentes histórias de vida dos sujeitos, promovendo convergências e divergências, encontros e desencontros. Para Freire (1986), a aula dialógica abre portas para que a professora e o professor ressignifiquem a própria prática por meio da reflexão porque "o diálogo requer uma aproximação dinâmica na direção do objeto" e, ainda “[...] não há o diálogo verdadeiro se não há nos seus sujeitos um pensar verdade (FREIRE, 1986, p. 65).

É nesse movimento permanente e reflexivo para a transformação entre prática e teoria, teoria e prática que a práxis ocorre continuamente porque o mundo não está pronto, completo, acabado. Deste modo, é possível pensar sobre como ressignificar os modos de ensinar a ler e a escrever revisitando o que as professoras fazem, não para buscar erros e equívocos, mas o que elas já realizam em sua prática pedagógica com as crianças que aprendem a ler e a escrever. Assim, reiteramos que "o desenvolvimento da 


\section{-Revista de Iniciação à Docência, v.6, n.2, 2021- \\ Publicação: dezembro, 2021 - ISSN 2525-4332}

teoria depende da prática" (SAVIANI, 2013, p. 91) e o fio que está entre as duas é o diálogo.

A leitura atenta a respeito da prática pedagógica colabora para pensarmos a formação continuada com um exercício permanente, colaborativo e, não apenas, cooperativo. Este indicativo, significa que há de ser considerado os saberes propostos por Freire (2019), entre os quais destacamos que ensinar exige rigorosidade metódica, respeito aos saberes do educando, pesquisa, saber escutar, amorosidade e, sobretudo, reflexão crítica sobre a prática.

Freire (1986), abarca a concepção de prática pedagógica que se constrói, na companhia dos sujeitos envolvidos, tendo em vista o conhecimento como processo em que ambos caminham na busca de práticas sociais que coadunam com a leitura crítica do mundo circundante. Assim, também deveria ser o movimento da formação inicial e continuada, firmada prioritariamente no diálogo, visando à produção de saberes em torno da prática pedagógica como inspiração e objeto de estudo.

O estudo da Prática Pedagógica na Formação Continuada Pacto e PNAIC surgiu como potência nos dados produzidos pelas professoras colaboradoras, assim compreendemos de acordo com Freire (2019, p. 11) que a "[...] reflexão crítica sobre a prática se torna uma exigência da relação Teoria e Prática sem a qual a teoria pode ir virando blábláblá e a prática, ativismo”. Nas palavras de Souza (2007) ao abordar que é na relação discente-docente que a prática se realiza, quer dizer, ambas contribuem na produção de conhecimento e de igual modo na formação dos sujeitos envolvidos.

A relação permanente entre teoria e prática diz sobre a práxis como um processo dialético, dialógico a partir da tríade: teoria-reflexão-ação. É nesse movimento espiralado que se materializa o compromisso entre o que se diz, pensa e, por conseguinte, realiza. Porque é preciso pensar acerca da própria história para participar dialogicamente da vida, por isso para Freire (2019) "pensar certo" promove fazer certo, isto significa que ao refletir sobre a prática pedagógica estarão professoras e professores ressignificando os próprios saberes.

Apresentaremos a seguir, alguns dados que são recortes de fragmentos das Cartas pedagógicas das professoras que contribuíram para o nosso estudo. Enfatizamos novamente que por se tratar de um recorte da dissertação omitimos as análises com base no arcabouço teórico de Bakhtin e Vygotsky.

O recorte dos dois ${ }^{4}$ trechos abaixo trazem os dizeres das professoras acerca da formação continuada:

\footnotetext{
4 Com vista a preservar a identidade das professoras, resolvemos denominá-la pelos nomes das personagens do livro Dandara, Cadê você? (MENDES, 2018). Sendo assim, iremos referendá-las por: Danda, Odara e Dione.
} 
Trecho 1: [...] a cada formação que participo procuro colocar em prática [as aprendizagens] para o melhor desempenho dos educandos no processo de ensino e aprendizagem com relação a leitura e a escrita de texto busco aprender a cada dia para melhor ensinar [...]

(Carta Pedagógica 1, Professora Danda, 13 fev. 2020).

Trecho 2: O programa Pacto- BA e PNAIC foi muito bom e despertou em mim vontade de aprender mais para ensinar ainda melhor aos meus alunos a leitura e escrita. Penso que a formação apresentou uma maneira nova de lecionar porque me ajudou a ver maneiras mais práticas para despertar o gosto de ler e de descobrir novas histórias infantis.

(Carta Pedagógica 1, Professora Dione, jun. 2020).

A formação continuada permeada pelo diálogo abriu portas para que as professoras refletissem acerca de suas práticas pedagógicas e buscassem como ressignificar o ensino de leitura e escrita. Passaram a ler mais textos literários de modo, considerando as especificidades deste gênero e, ao mesmo tempo, aguçaram um olhar mais atento para o que está nas entrelinhas. No "chão da escola" os desafios são permanentes e exigem das professoras e dos professores um "olhar mais crítico possível da realidade, que a 'des-vela' para conhecê-la e para conhecer os mitos que enganam" (FREIRE, 1980, p. 29). Sendo assim, nas palavras de Freire:

[...] não posso, por isso mesmo, burocratizar meu compromisso de profissional, servindo, numa inversão dolosa de valores, mais aos meios que ao fim do homem. Não posso me deixar seduzir pelas tentações míticas entre elas a da minha escravidão às técnicas, que sendo elaboradas pelos homens, são suas escravas e não suas senhoras (FREIRE, 1979, p. 20).

A educação emancipatória, proposta pela pedagogia freireana está ancorada em vivências e participação crítica, a partir do diálogo comprometido com produções colaborativas, que rompam com o silenciamento do outro. Deste modo, Freire (2019) reitera que nenhuma professora e nenhum professor devem cruzar os braços diante dos obstáculos, mesmo quando não é possível mudar a sua própria realidade, porque a esperança é a bússola, apesar de tudo. A esperança do verbo esperançar aquela que impulsiona ação, luta, resistência.

O trecho abaixo ilustra alguns pontos referentes ao encontro e o acesso à leitura e a escrita, por parte da professora e como essa conexão se organiza na prática pedagógica de cada uma.

Trecho 3: Relatar como foi o primeiro contato com a leitura e a escrita é relembrar a minha infância que não foi nada fácil pois, para chegar na escola que estudava precisava andar a pé por 6 quilômetros e, muitas vezes, não tinha nem cadeira para sentar, como também não tinha transporte escolar para locomoção dos alunos de casa para a escola. $O$ meu contato com os livros era somente na instituição. Lembro-me de que fiquei muito feliz quando ganhei de presente um gibi. Esse foi o primeiro contato com a leitura fora da escola.

(Carta Pedagógica 1, Professora Danda -13 fev. 2020).

Nesse trecho, retirado da Carta Pedagógica 1, constatamos as dificuldades da professora Danda para ter acesso ao conhecimento promovido pela escola. Era nesse 
local que ela tinha contato com as "vozes dos livros". Ela nos relata qual foi a sua alegria ao ganhar um livro de presente, fazendo-nos rememorar também nossa trajetória pessoal, reafirmando o quanto as marcas desse lugar de aluna se interpenetram com a vida pessoal e profissional. Os livros estão carregados de vozes que dormem e, ao serem lidas, acordam para assentar na imaginação, na reflexão, na construção de outros conhecimentos.

Para a professora que atua em uma turma multisseriada, hoje sabe que é possível descobrir lendo e é, por isso também, que esse gosto contribuiu para ancorar a sua prática pedagógica, referente ao ensino da leitura. A infância pobre não a acomodou, ao contrário, aguçou o seu gosto pela leitura, acentuando em sua prática pedagógica a necessidade de ler cada vez mais e de ler não apenas para, mas também com as crianças na escola, considerando como para as crianças esta leitura diária é tão necessária. Freire (2003) relata acerca da própria infância e de como as reflexões sobre ela o ajudou aprender sempre. As reminiscências não são vazias, mas sobre como as dificuldades o desafiaram a sair da acomodação, abrindo janelas para um olhar curioso, marcado pelo verbo denominado por ele de esperançar.

A professora Danda insistia em" trabalhar a leitura todo dia", isso significa que havia um rigor nesse fazer, todavia nem sempre esse esforço resultava em aprendizagem da criança, conforme concluiu ainda na primeira Carta Pedagógica.

Trecho 4: [...] é importante destacar que o gosto e a vontade em aprender sempre foi maior que qualquer coisa. Amava ouvir as histórias do conto de fadas que sempre tinham um final feliz, que minha professora contava para mim. Hoje busco a leitura como fonte de prazer e encantamento e procuro através do meu trabalho conduzir a leitura de modo prazeroso para despertar nos alunos a vontade de aprender a ler $e$ escrever para melhor desenvolvimento da aprendizagem. Trabalho com a leitura individual todos os dias na minha sala de aula, principalmente com os alunos que mais têm dificuldade na leitura.

(Carta Pedagógica 1, Professora Danda -13 fev. 2020).

Percebemos que o fato de ter ouvido muitas histórias, contadas pela professora na infância foi um fator que em muito contribuiu para que a professora Danda em sua prática pedagógica tomasse a leitura para si "como fonte de prazer e encantamento" porque descobriu a função social do livro e, por conseguinte, começou a levantar as palavras que dormiam nas histórias para, mais adiante, também "despertar nos alunos a vontade de aprender a ler e escrever para melhor desenvolvimento da aprendizagem". $\mathrm{E}$ ela insiste nessa necessidade de ler na sala de aula ao enunciar "principalmente com os alunos que têm dificuldade a leitura".

Trecho 5: O meu encontro com a leitura e escrita de texto foi de forma encantadora e prazerosa. 0 tempo todo a curiosidade me levava ao universo de conhecimento. Na escola, gostava de ouvir e ler contos de fadas como a de João e Maria e outros contos narrativos e me deleitava com atitudes das personagens e me imaginava na situação vivida por eles. Vale destacar que os contos populares, cantiga de roda sempre fizeram parte da minha trajetória escolar e até hoje fazem parte da rotina do meu trabalho como professora alfabetizadora.

(Carta Pedagógica 1, Professora Odara-10 mar. 2020). 
Semelhante à professora Danda, a professora Odara, nesse trecho 5 trouxe a leitura e escrita como prazer, encantamento, curiosidade e valorização dos contos e cantigas populares. Esses fatores contribuíram para sua prática alfabetizadora. Ambas reafirmam a respeito não apenas do significado, mas do sentido que a leitura representa na própria vida. O diálogo entre leitura e escrita na escola e fora dela que vão tecendo a vida porque " é o diálogo o encontro entre os homens, mediatizados pelo mundo, para designá-lo” (FREIRE, 1979, p. 42).

Leitura e escrita precisam ser ensinadas para um pensar crítico, logo desvinculadas das frases prontas, mas tomadas das experiências dos sujeitos. Esse modo de ensinar nega a "educação bancária" alicerçada na transferência de conhecimento. Assim, para Freire (2009), o ato de estudar alimenta a curiosidade do sujeito diante das coisas do mundo, mostrando-lhes que ocupa um lugar como ser humano, que tem história e que não sabe por saber, mas sabe para agir, tomar decisões.

No trecho a seguir (6), a professora Dione aponta suas dificuldades para lecionar por um longo período em classes multisseriadas.

Trecho 6: [...] minha primeira sala de aula foi em uma escola do campo, sala multisseriada. No começo foi muito difícil, não sabia lidar com aquelas crianças cada uma em uma série diferente. Passei 5 anos trabalhando com a turma multisseriada. Desde então aprendi muito [...] tive várias experiências e sei que fiz um ótimo trabalho.

(Carta Pedagógica 1, Professora Dione-05 abr. 2020).

A professora Dione sinaliza nesse trecho que "tinha muita dificuldade em lidar com aquelas crianças cada uma em uma série diferente. Porém, o fato de ela ter afirmado enfaticamente que fez um "ótimo trabalho", entendemos que houve tentativas de vencer os entraves que se apresentaram em busca de uma prática reflexiva.

Nessas condições de aprendizagem, Freire (2019, p.26) afirma que "os educandos vão se transformando em reais sujeitos da construção e da reconstrução do saber ensinado, ao lado do educador", sujeito consciente do inacabamento, logo também parte permanente do processo que entrelaça aprendizagem e ensino.

De acordo com Freire (2011, p. 87), "o conhecimento envolve a constante unidade entre ação e reflexão sobre a realidade", esse movimento indica para a professora e o professor a possibilidade de permanentemente ressignificar a prática, por isso Freire (1997) lança uma pedagogia fundada na ética, no respeito à dignidade, bem como na autonomia do educando, sendo ele(a) criança, jovem, adulto e idoso.

Na carta, a professora Dione não explicitou quais as "dificuldades" da turma além da diferença do nível de escolaridade. No entanto, em nossas conversas via Whatsapp e Google Meet, ela chegou a mencionar algumas delas: planejamento para cada ano com atividades específicas em consonância com o currículo; mediação, ao mesmo tempo, com diferentes níveis de aprendizagem referentes à leitura e a escrita, com foco em cada ano; 
escuta das crianças e das famílias, sem perder de vista as aprendizagens para cada ano; seleção de atividades, etc. $O$ fato de a professora ter afirmado enfaticamente que fez "um ótimo trabalho" nos propõe a intuir que houve a busca de uma prática efetiva, mesmo que não tenha sido a ideal.

O Trecho 7 traz um questionamento da professora Danda provocado pela reflexão que ela faz acerca de como ressignificar o ensino da leitura e da escrita. Já a professora Odara, Trecho 8 registra uma preocupação mais específica que está presente na sala de aula referente à efetivação da inclusão das crianças com necessidades especiais com a finalidade de ler e escrever na escola e na vida social.

Trecho 7: E então, como professora o que devo fazer para melhorar a prática de leitura e escrita de texto para poder ensinar melhor aos meus alunos?

(Carta Pedagógica 1, Professora Danda-13 fev. 2020).

Trecho 8: Desejo ampliar/ampliar estudos na área da educação inclusiva, de forma a ajudar incluir alunos com necessidades especiais a se encantarem na escrita e leitura, principalmente os que estão no $3^{\circ}$ ano sem saber ler e escrever. Quero ver formas de ensinar esse público a sentir prazer no estudo e no mundo letrado. (Carta Pedagógica 1, Professora Odara-10 mar. 2020).

Essas reflexões das professoras colaboradoras referentes aos trechos acima reiteram que elas seguem ressignificando os saberes da experiência em relação ao ensino da leitura e da escrita, mas sentem a necessidade de mais conhecimentos específicos para lidar melhor com os 'alunos' que apresentam necessidades especiais. Há nas linhas e entrelinhas lutas e resistências porque elas sabem que "ninguém nasce feito. Vamos nos fazendo aos poucos na prática social de que tornamos parte" (FREIRE, 2001, p. 44). Cada professora assumiu a necessidade de diálogo, da escuta de outras vozes que contribuíssem para o desenvolvimento de sua prática pedagógica, no que se refere ao trabalho com a leitura e a escrita.

Quando a professora Danda afirma que quer "ensinar melhor aos alunos", isso não significa que não ensine bem. Ao contrário, essa reflexão promove a busca pelo estudo permanente, consciente que já é do lugar que ocupa na sala de aula e do compromisso humano que tem com as aprendizagens das crianças. Durante todo processo da pesquisa, essa preocupação foi muito evidente nas três professoras.

Elucidamos, com base no exercício crítico e consciente do lugar ocupado pela docência que a prática pedagógica por intermédio dos estudos freireanos, cuja base é o movimento, a busca, a reflexão acerca do fazer e sobre como fazer para assim, refazê-lo e, nesse encadeamento também refazer-se exige decência. Deste modo, não há ensino fora da autoridade coerentemente democrática, da generosidade, de pensar certo e, por conseguinte, fazer certo para, assim fundamentar a prática no exemplo. Freire (2019).

O movimento espiralado do fazer das professoras em busca da ressignificação dos modos de ensinar a leitura e a escrita anuncia "[...] a rebeldia que me confirma como gente e que jamais deixou de provar que o ser humano é maior do que os mecanicismos 


\section{-Revista de Iniciação à Docência, v.6, n.2, 2021- \\ Publicação: dezembro, 2021 - ISSN 2525-4332}

que o minimizam." (FREIRE, 2019, p. 112-113). É com esta sabedoria que professoras e professores, contrariam a ideologia neoliberal e resistem tomando para a si a luta por uma educação viva que contribua para a vida do sujeito criança. A arma que usam em suas rotinas desafiadoras é o conhecimento. São anônimos aos olhos dos governantes, mas referências para muitas crianças.

É imprescindível que as universidades entrem na luta política com a Educação Básica, pelo direito da criança pobre, negra, indígena (maioria nas escolas da rede pública) aprender a ler e escrever com sentido, considerando as próprias experiências discursivas dessas crianças. Esta prática pedagógica demanda mediação qualitativa, com vistas a potencializar a construção do conhecimento pelas crianças, desde cedo.

A leitura atenta a respeito da prática pedagógica colabora para pensarmos a formação continuada com um exercício permanente, colaborativo e, não apenas, cooperativo. Este indicativo, significa que há de ser considerado os saberes experienciais como propõe Tardif (2003) uma vez que "formar é formar-se" (NÓVOA, 1995, p. 9), por certo, esse formar-se está intimamente ligado ao convívio demarcado pela interação entre colegas e, por conseguinte, com as crianças porque conforme anuncia Freire (2019, p. 25).

[...] quem ensina, aprende ao ensinar, e quem aprende, ensina ao aprender. Não há ensino sem pesquisa e pesquisa sem ensino. Enquanto ensino, continuo buscando, reprocurando. Ensino porque busco, porque indaguei, porque indago e me indago. Pesquiso para constatar, constatando, intervenho, intervindo educo e me educo. Pesquiso para conhecer o que ainda não conheço e comunicar ou anunciar a novidade.

Reconhecermos que a transformação não ocorre porque está documentada, assim relembrando as palavras de Freire (2019), proferir a palavra é também pronunciar o mundo, é delimitar o próprio lugar na história porque como sujeitos somos seres da práxis e, portanto, seres humanos ao mesmo tempo teórico-prático e reflexivos.

\section{Conclusão: deixando a porta aberta a novos diálogos}

"Pesquiso para conhecer o que ainda não conheço
e comunicar ou anunciar a novidade".

Foi consciente das reflexões explicitadas por Moraes (2013) que passamos às análises do processo de produção de dados, trazendo para o campo as linhas tecidas na travessia pelas professoras, por meio de novas compreensões acerca da prática pedagógica referentes ao ensino da leitura e da escrita no contexto formação continuada do Pacto e PNAIC.

Discutimos com as professoras colaboradoras acerca das seguintes questões: ressignificações das práticas pedagógicas para ensinar a ler e a escrever, desde quando 


\section{-Revista de Iniciação à Docência, v.6, n.2, 2021- \\ Publicação: dezembro, 2021 - ISSN 2525-4332}

passaram a organizar os planejamentos, considerando-os como momentos específicos de estudo; a elaboração das atividades com mais atenção aos saberes das crianças, de modo coletivo e individual; a mediação relacionada aos níveis de escrita para mediar as intervenções e, não com a intencionalidade de classificar as crianças; a compreensão da leitura pelas crianças e o trabalho sistemático com a consciência fonológica como um momento do processo de alfabetização.

Neste sentido, compreendemos que os saberes de quem ensina não são constituídos apenas por meio da quantidade de formação que cada professora e professor vão acumulando no exercício da docência, mas, sobretudo, do que cada profissional de leitura e escrita "aprende ao ensinar" Quem aprende permanece buscando aprender estabelecendo uma relação viva entre a prática e a escuta das vozes dos outros que dizem sobre a teoria.

Defendemos que o ensino e a aprendizagem devem estar se pautados nas experiências sociais que emergem da palavra viva de cada sujeito, da reflexão a respeito da palavra que escuta e diz com a finalidade de interagir com outros.

O diálogo em consonância com o pensamento freireano abre portas para a liberdade da criança e da professora porque ambas estão aprendendo, tendo a linguagem como pela interação mediada por diferentes ferramentas digitais. Foi com essa sintonia que cada professora, mais uma vez, ressignificou a prática pedagógica do ensino de leitura e escrita para, no contexto da cibercultura, de dentro de suas casas, bancando os próprios equipamentos tecnológicos, o custo da internet e horas e horas entre cursos disponíveis gratuitamente para sustentar a educação do Brasi, durante a pandemia. Deste modo, diminuíram a ausência das políticas públicas em todas as instâncias do governo, sem romantizar, e levaram a escola para cada família com pouco ou quase nenhum acesso à internet. Assim, as professoras e as famílias resistiram e possibilitaram o desenvolvimento e a aprendizagem das crianças.

\section{Referências}

BAKHTIN, Mikhail. Estética da criação verbal. 6.ed. São Paulo: Editora WMF Martins Fontes, 2011.

FREIRE, Paulo. Cartas a Cristina: reflexões sobre minha vida e minha práxis. $2^{\mathrm{a}}$ ed. São Paulo: UNESP, 2003.

FREIRE, Paulo. A importância do ato de ler: em três artigos que se completam.50.ed. São Paulo: Cortez, 2009.

FREIRE, Paulo. Conscientização: teoria e prática da libertação, uma introdução ao pensamento de Paulo Freire. São Paulo: Moraes, 1980.

FREIRE, Paulo. Educação e mudança. Rio de Janeiro: Paz e terra, 1979

FREIRE, Paulo. Medo e Ousadia - O Cotidiano do Professor / Ira Shor, Paulo Freire; 
tradução de Adriana Lopez; revisão técnica de Lólio Lourenço de Oliveira. - Rio de Janeiro: Paz e Terra, 1986.

FREIRE, Paulo. Pedagogia da autonomia. 61 ${ }^{\text {aa }}$ ed. Rio de Janeiro: Paz e Terra, 2019.

FREIRE, Paulo. Pedagogia do Oprimido. São Paulo: Paz e Terra, 2011.

FREIRE, Paulo. Política e educação: ensaios. 5. ed. São Paulo: Cortez, 2001. (Coleção Questões de Nossa Época; v.23)

FREIRE. Paulo. Pedagogia da esperança. $13^{\mathrm{a}}$ ed. Rio de Janeiro: Paz e Terra, 2006.

IBIAPINA, I.M.L.de M.; BANDEIRA, H.M.M.; ARAÚJO, F.A.M. (Orgs.). Pesquisa colaborativa: multirreferenciais e práticas convergentes. Teresina/Piauí: EDUFPI, 2016.

IBIAPINA, Ivana Maria Lopes de Melo. Pesquisa Colaborativa: investigação e produção de conhecimentos. Brasília, DF: Liber Livro: 2008.

NÓVOA, A. Vidas de professores. Porto: Porto Editora, 1992.

NÓVOA, António. Os professores e o novo espaço público da educação. In Educação e sociedade: perspectivas educacionais no século XXI. Santa Maria: Centro Universitário Franciscano, pp. 19-45. 2006.

NÓVOA, Antônio. Vidas de professores. Porto: Porto Editora, 1997

SAVIANI, Demerval. Pedagogia histórico-crítica: primeiras aproximações. 2. ed. Campinas, SP. Autores associados, 2013.

SOUZA, Ester Maria de Figueiredo Souza. FERREIRA, Lúcia Gracia. A prática como componente curricular: (re)indagações para a formação docente. Revista Práxis Educacional, Vitória da Conquista, Bahia, Brasil, v. 15, n. 34, p. 195-210, Edição Especial, 2019. Disponível em: http://periodicos2.uesb.br/index.php/praxis/article/view/5505/4183. Acesso em: 29 nov. 2019.

TARDIF, M. Saberes docentes e formação profissional. 3 ed. Petrópolis, RJ: Vozes, 2003.

VYGOTSKY Lev Semenovich; LURIA, Alexander Romanovich; LEONTIEV, Alexis N. Linguagem, desenvolvimento e aprendizagem. Tradução de Maria da Penha Villalobos. 2. ed. São Paulo: Ícone, 1988.

VYGOTSKY, L. S. Pensamento e Linguagem. São Paulo: Martins Fontes, 2005.

VYGOTSKY, L.S. A formação social da mente. 4. ed. São Paulo: Martins Fontes, 1991. 